\title{
CARBON TRADING ACCORDING TO INTERNATIONAL LAW AND ITS IMPLEMENTATION IN INDONESIA
}

\author{
Shinta Wahyu Purnama Sari and Widya Krulinasari \\ Law Faculty, University of Lampung \\ email: shintasari.tata@gmail.com \\ email: krudick_hi@yahoo.com
}

\begin{abstract}
This research aims to describe the carbon trading according to international law and its implementation in Indonesia. It uses juridical-normative research methods. Climate change is one of the major environmental issues in the world, it causes an adverse effect to human life. Basically it comes from human activities. To follow up the issue, then countries try to solve it by taking an action to reduce the emissions. Through the first Earth Summit in Rio De Janeiro-Brazil in 1992, which produces the Convention on Climate Change (UNFCCC); one of the achievements of the UNFCCC is the Kyoto Protocol, wherein the Protocol contains two important things, namely the commitment of developed countries to reduce the rate of emissions compared to 1990, and the possibility of carbon trading mechanisms. Indonesia is one of the countries that have ratified both the UNFCCC through Law No. 6 of 1994, and the Kyoto Protocol through Law No. 17 of 2004. There are also some related regulations. However, of all existing laws, the government has not put out implementing regulations or instructions about carbon trading specifically.
\end{abstract}

Keywords: Carbon Trading, International Law, Indonesia.

\section{A. Introduction}

Global environmental issue is not entirely new. Nowadays, it just becomes a serious attention in almost all countries, especially at the aspect of law and policy. Environmental problems do not only occure in developed countries, but also in developing countries. ${ }^{1}$ Climate change is a global phenomenon caused by natural variability or as a result of human activities such as fossil fuel use in large scale (coal, oil and natural gas), land use change (clearing land for logging, farming and agriculture), activity over

\footnotetext{
${ }^{1}$ Muhammad Akib, Aktualisasi Politik Hukum Lingkungan Dalam Penyelenggaraan Otonomi Daerah, (Bandar Lampung : Universitas Lampung, 2015), p, 1.
} 
land uses and forestry, and consumerism. ${ }^{2}$ Time of taking and using these resources, greenhouse gases released massively into the atmosphere due to industrial processes. Other gases are also released and polluting the atmosphere, such as carbon dioxide $(\mathrm{CO} 2)$, methane $(\mathrm{CH} 4)$, dinitroksida (N20). All these gases are called "greenhouse gases".

Human activities are a major source of greenhouse gases (GHG) and the biggest factors of climate change, especially carbon dioxide $(\mathrm{CO} 2)$; the largest contribution coming from industrial countries. $\mathrm{CO} 2$ has the ability to absorb heat coming from solar radiation re-emitted by the earth. The absorption has led to the atmospheric warming or rising temperatures and climate change. The greenhouse gases emissions continue to rise and impact to local and also worldwide. ${ }^{3}$

Since the industrial revolution 250 years ago, the concentration of GHGs in the atmosphere has increased at an alarming rate. In pre-industrial, the concentration of carbon dioxide in the atmosphere rose sharply, the climate adapt to the sheath of GHG, at the Earth's surface and in the lower atmosphere. ${ }^{4}$ The world body that tasked to monitore the climate issue is "Intergovernmental Panel on Climate Change" / IPCC; it has estimated that between 1750 and 2005 the concentration of carbon dioxide in the atmosphere increased by $280 \mathrm{ppm}$ (parts per million) to $379 \mathrm{ppm}$ per year and since then, continued to increase at a speed of $1,9 \mathrm{ppm}$ per year. As a result, in 2100, global temperatures can rise to 1.8 till 2.9 degrees (IPCC, 2007). This has led to concerns about the sustainability of the earth. ${ }^{5}$

There are some efforts made by the international societies in environmental protection today, namely repressive and preventive efforts. The preventive measures carried out by reducing the activity that produces greenhouse gases (GHG) and reducing the use of ozone depleting substances; maintain the existance of green open areas, in order to maintain the presence of water catchment areas as well as carbon sinks; raise awareness of the environmental data of sea, land and air; undertake spatial planning that combines marine, coastal and land spatial plannings; and

\footnotetext{
${ }^{2}$ Rumah Iklim.org, Perubahan Alim, http://rumahiklim.org/masyarakat-adat-dan-perubahaniklim/apa-itu- perubahan-iklim/mengapa-perubahan-ikliln-terjadi/

${ }^{3}$ Rumah Iklim.org, Apa itu perubahan iklim? http://rumahiklim.org/masyarakat-adat-danperubahan-iklim/apa-itu-perubahan-iklim/

${ }^{4}$ BreakingNews, http://ahlulbaitindonesia.org/berita/7518/bijak-dan-cerdas-hadapi-tantanganperubahan-iklim-di-indonesia-2/

5 Prabang Setyono , Etika, Moral, Dan Bunuh Diri Lingkungan Dalam Perspektif Ekologi (Solusi Berbasis Environmental Insight Quotient, Lembaga Pengembangan Pendidikan (LPP), (Universitas Sebelas Maret Surakarta : Jawa Tengah, 2011), p. 109. http://lpp.uns.ac.id/bukuteks/images/flippingbook/Etika,\%20Moral\%20dan\%20Bunuh\%20 Diri\%20Lingkungan\%20dalam\%20Perspektif\%20Ekologi,\%20Dr.\%20Prabang\%20Setyon o,\%20M.Si/pdf/etika,moral.pdf.
} 
increase public awareness of the effort to prevent the escalation of global warming. Whereas, the repressive efforts to do among others by improving facilities and infrastructure for flood prevention and drought; rehabilitate degraded land by way of promoting the planting of trees (reforestation) as an effort to absorp the carbon gases, and increase the availability of water reserves; improved handling of environmental and coastal habitat; society health services ${ }^{6}$; and emissions reductions through carbon trading.

States should implement the reduction of greenhouse gas emissions, and developing countries are initiatives take an action to reduce the emissions. One way is to increase the ability of the land and forests. Because land and forests can absorb greenhouse gases. Indonesia has the potential for it, because Indonesia is a country with tropical forests. Indonesia is the third largest country that has the largest tropical forest in the world and got first ranked in Asia-Pacific. The width of Indonesia's tropical rainforest estimated to 1.1484 million square kilometers. ${ }^{7}$

Forests as carbon stores must be preserved. Forests and natural areas have a very important role in maintaining the natural process. It is one of the biggest carbon sinks that help keep the carbon cycle and other natural processes work well and help reduce greenhouse gas emissions. But, what about countries that do not have any sufficient land or tropical forest?; it will certainly pose a problem, because not all countries have tropical forest and land. Then, the solution is cooperation with other countries that have a more tropical forests, so as to divide the carbon in order to tackle the problem of global warming.

Cooperation was presented and agreed upon in the form of the International covenant, which called the United Nations Framework Convention on Climate Change (UNFCCC) ${ }^{8}$. There is a principle in the UNFCCC activities, known as Common but Differentiated Responsibility. This principle refers to the fact that developed countries that first releasing greenhouse gases massively to the atmosphere when carry out the development in their respective countries. ${ }^{9}$ After gained the development benefits, then, developed countries had higher levels of greater responsibility to reduce greenhouse gas emissions and help developing countries to mitigate and adapt. This principle also underlies the development of a more

\footnotetext{
${ }^{6}$ Nawa Suwedi, Upaya Pencegahan dan Penanggulangan Dampak Pemanasan Global, p. 400-401. Accesed by: http://ejurnal.bppt.go.id/index.php/JTL/article/view/431/495, on 5 January 2016, 18.02 WIB.

7 Word Agroforestry Centre Southwest Asia, Publication, http://worldagroforestry.org/ regions/southeast_asia/publications?do=view_pub_detail\&pub_no=TD0171-12.

${ }^{8}$ UNFCCC : International Agreement on Climate Change.

9 Dewan Nasional Perubahan Iklim, Mari berdagang karbon!, (Jakarta : Sekretariat DNPI, 2013) worldagroforestry.org/regions/southeast_asia/publications?do=view_pub_ detail\&pub_no=TDO171-12, p. 7 .
} 
or less carbon trading and carbon markets, where the parties have a responsibility to reduce greenhouse gas emissions but can not do it themselves, but they can be "ordered" the parties / other countries to do so on its behalf. With the parties who require a reduction in emissions and a party who can supply the required emission reduction, then carbon trading and carbon markets formed. ${ }^{10}$

UNFCCC has been adopted by 195 countries, including Indonesia, which ratified it by Law No. 6 of 1994. One of important achievements in the Convention is the Kyoto Protocol in 1997. The Protocol obligating the developed countries to reduce greenhouse gas emissions as much as an average 5 percent below the level in 1990. This Protocol became effective in 2005, while Indonesia ratified it by Law No. 17 of 2004.

Carbon trading means there are rights and obligations of the parties, where tropical forest countries are required to maintain their forests to soak up global warming and industrial countries pay the developing countries that have maintained the forests. But, what about the provisions? Because the problem is how and what will tropical forest countries get from industrial countries that sent them to reduce greenhouse gas emissions to maintain and protect their forests. ${ }^{11}$

The trade will be regulated by an international agreement, and also national arrangements, because Indonesia is one of the countries that ratified it. Indonesia as a country that has the potential of tropical forests should have been able to reduce the emissions of greenhouse gases.

Based on the background described above, the problems can be formulated as follows: 1) How is the regulation of carbon trading according to International Law?; and 2) How is the implementation of carbon trading in Indonesia?

The method used in this research is the method commonly used in the science of law, namely, juridical-normative methods.

\section{B. The Regulation of Carbon Trading According to International Law}

Nowadays, international socities are busy talking about the Global Warming and Climate Crisis. Review on the global warming, the danger, as well as solutions to inhibit the increase is intensively discussed by various media in the world. Concerns about climate change conditions that getting worse become a serious concern for worldwide countries. Joint efforts have been made to discuss the causes of climate change, its effect on the survival

\footnotetext{
${ }^{10}$ Ibid.

${ }^{11}$ Kompas.com, Perdagangan karbon, bagaimana menurut anda ?, http://forum.kompas.con/ green-global-war ming/28753-perdagangan-karbon-bagaimana-menurut-anda.htmI.
} 
of human beings, and how to mitigate them. Climate change is caused by human activities that increase greenhouse gas emissions.

Since "Stockholm Declaration of 1972" declared by the international socities wherein environmental issues became the limelight of the international socities as reflected in Principle 22 of the Declaration; stipulates that:

"State shall co-operate to develop further the international law regarding liability and compensation for the victims of pollution and other environmental damage caused by activities within the jurisdiction or control of such States to areas beyond their jurisdiction."

Stockholm Conferences in 1972 was not able to prevent environmental damage, so that the environmental damage is increasingly severe. A decade after the implementation of the Stockholm Conference in 1972, international socities seek to reduce the environmental damage. Then, World Commission on Environment and Development completed its work in 1987 and announced its report, known as the Brundtland Report, entitled Our Common Future Day. The theme of the report was Sustainable Development. $^{12}$

Sustainable development is intended as a long-term development, covering the period between generations which are not greedy for its own sake, but also taking into account the interests of our children and grandchildren with trying to leave sufficient resources and a healthy environment as well as the support of human life prosperously. ${ }^{13}$

In less than twenty years after the implementation of the Stockholm Conference in 1972, on 3rd June until 14th June, 1992 in Rio de JaneiroBrazil, was held Conference of the United Nations on Environment and Development (United Nations Conference on Environment and Development), known also as the earth Summit to discuss about the safety of earth. The Earth Summit, which was attended by around 100 heads of state and government had resulted: (1) Rio Declaration; (2) Agenda 21; (3) Convention on Climate Change; (4) Convention on Biological Diversity, and (5) Forest Principles. ${ }^{14}$

United Nations Framework Convention on Climate Change as one of the result in the Earth Summit recognizes that human activities increase the concentration of greenhouse gases (GHGs) in the atmosphere and will lead

\footnotetext{
12 Repository. Diakses: http://repository.usu.ac.id/bitstream/123456789/25539/3/ Chapter\%20II.pdf, on 04 May 2015, 18.00 WIB.

${ }^{13}$ Anto Ismu Budianto, Hukum dan Lingkungan Hidup Di Indonesia, (Jakarta: Perpustakaan Nasional, 2001), p. 191.

${ }^{14}$ Ibid., p. 192.
} 
to global warming and climate change. ${ }^{15}$ These changes will then result in adverse effects on natural ecosystems and human beings.

In terms of commitment, Article 4 of the UNFCCC discuss what the $\mathrm{UN}$ is supposed to accomplish. One of the most important is the developed countries adopt it into national policies and take measures to mitigate the climate change through greenhouse gas emission limitations. ${ }^{16}$ UNFCCC formed Conference of the Parties (COP) to carry out the work, to adopt and make the decisions necessary to promote the effective implementation of this Convention. ${ }^{17}$

The first session of the COP was held in Berlin, Germany. Each session of the COP is generally ended with an agreement that usually refers to the name of where the trial held. Eg COP-1 in Berlin, the result is called the "Berlin Mandate"; COP-13 in Bali, known as "Bali Action Plan" (BAP); COP-11 in Montreal, known as the "Montreal Protocol", and so on. But not all of the COP ends with the result that satisfies all parties for one reason or another, and thus many of its members UNFCCC (over 190 countries). One of them is the COP-15 in 2010 in Copenhagen, the result is called as "Copenhagen Accord". Although the deal had achieved significant progress, but because it was not conducted in a transparent and democratic, then at first, it was lacking a lot of support. However, lately many countries recognize important points are reached and then provide the supports. ${ }^{18}$

Since the negotiations of the global climate change in 1995 until today, if seen from the resulting agreements, only occurs twice as important achievements. The achievement have a great impact on the settlement of the problem of global climate change in the long term. The first one was in 1997, COP-3 in Kyoto-Japan, resulted the "Kyoto Protocol : and the second one, ten years later, in the 2007 Bali (COP-13), resulted the" Bali Action Plan "(BAP). ${ }^{19}$

COP-3, held in Kyoto-Japan, resulting one of the significant achievements, namely the "Kyoto Protocol" (KP). KP essentially contains two important things. First, the commitment of the developed countries or Annex 1 parties to reduce the average emissions rate of 5.2\% compared to 1990; and second, allowing the carbon trading mechanism through the clean development mechanism-CDM, joint implementation-JI; and emission

\footnotetext{
${ }^{15}$ UN Framework Conventions on Climate Change (UNFCCC). 9 Mei 1992, (Entry into force on 21 March 1994) 1771 UNTS 107.

${ }^{16}$ UNFCCC. Article 3.

${ }^{17}$ UNFCCC. Article 4 Paragraoh (2) (a).

18 Doddy S. Sukardi. Kerjasama antara Kemntrian Kehutanan, DNPI dan UN-REDD Indonesia. UN-REDD Programme, Diakses: http://www.unredd.net/index.php?option=c om_docman\&task=doc_download\&gid=8850\&Itemid=53, on 04 May 2015, 20.50 WIB.

${ }^{19}$ Ibid.
} 
trading-ET. Mechanism of Joint Implementation and Emission Trading is a mechanism that is carried out among developed countries with other developed countries, while the third is carried out among developed and developing countries. ${ }^{20}$

Until August 2011, the number of States that have signed and ratified the Kyoto Protocol, totaled 191 countries. 189 of them are members of the UN and the remaining two are the Cook Islands and Niue and the European Union. The Kyoto Protocol was actually issued on 11 December 1997. The actual effectiveness of the protocol did not occur until February 16, 2005, when a sufficient number of countries to ratify that protocol.

The general principles of the Kyoto Protocol aimed to the reduction of greenhouse gases by developed countries and the ability to expand credit for reducing emissions and allowance trades and compensation internationally. ${ }^{21}$ This provision led to the emergence of international "carbon market," which then called by the credit trading, which is measured in carbon dioxide equivalent, so that the term referred to the carbon credits.

As was explained earlier that in terms of reducing the rate of greenhouse gas emissions, the Kyoto Protocol regulates the carbon trading mechanism, which has been known as the "flexible mechanisms", and those mechanisms among others: ${ }^{22}$

\section{Emissio Trading (ET)}

ET regulated under Article 17 of the Kyoto Protocol which is the trading of units of Kyoto credits, includingsome of assigned amonts, CERs, ERUs, and others, among the countries in Annex I. A few things to note relating to ET are:

a. The total emission cap of Annex I Parties will not change;

b. Only Annex B Parties of the Kyoto Protocol may participate in ET (Emission Trading);

c. The minimum unit that can be traded amounted 1t-CO2 equivalent; and

d. Through the market mechanism, ET can decrease total cost of Annex-1 to obtain their collective emission reduction targets.

\section{Clean Development Mechanism (CDM)}

CDM regulated under Article 12 of the Kyoto Protocol that allows Annex I Parties which have the highest limit for emissions of greenhouse

\footnotetext{
${ }^{20}$ Ibid.

${ }^{21}$ Scott D. Deatherage, Carbon Trading Law and Practice, (New York: Oxford University Press, 2011), p. 42.

${ }^{22}$ Syahrina. D. Anggraini. CDM dalam Bagan Ver.9.0. (Jakarta: Carbon and Environtmental Research (CER) Indonesia: 2009). p. 6-8.
} 
gases that have been set (emission caps) help countries Non-Annex 1 that do not have emission caps, to implement project activities to reduce GHG emissions (or increases absorption) and emission reduction credits will be issued based on emission reductions (or removals by sinks) achieved by the project activity. Some things to note related to the CDM, among others: ${ }^{23}$

a. The credit from the CDM is called certified emission reduction (CER);

b. Annex 1 countries can use CERs to meet the GHG emissions reduction targets under the Kyoto Protocol;

c. Reductions in emissions shall be additional to any that would occur in the absence of the CDM project activity;

d. As a result, the amount of emission cap of Annex 1 will increase; and

e. CERs generated from activities conducted in the period from 2000 to 2012 can be used to meet the emission reduction targets of Annex 1 countries in the first commitment period.

\section{Joint Implementation (JI)}

This mechanism can be found in Article 6 of the Kyoto Protocol. In this mechanism, the Kyoto Protocol allowing Annex 1 countries that have excess quota of greenhouse gas emissions (emission caps) can help the other Annex 1 countries who have no cap, to implement project activities to reduce GHG emissions (or raise the absorption), and carbon emissions reduction credits will be issued based on the number of emission reduction (or increase sinks) achieved by the project activities. The few things that need to be considered related to JI, among others:

a. emission reduction credits from JI are called Emission Reduction Unit (ERU);

b. Every JI's project should be able to absorp GHG emissions reductions, and it is additional to any that would occur without the project;

c. Annex 1 countries can use ERUs to fulfill the GHG emissions reduction targets under the Kyoto Protocol;

d. Total cap emissions of Annex 1 countries will not change, because jI just a transfer between Annex 1 countries that have the same emission cap; and

e. ERUs issued after 2008.

Rules to implement the Protocol occurred in 2001 at COP-7, the rule is known as the "Marrakesh Accords." As stated above, the conference of the Parties to the UNFCCC referred to as COP. The meeting also includes the Meeting of the Parties to the Kyoto Protocol (MOP). Thus, this meeting is known as the COP / MOP. The meeting in Marrakesh for COP / MOP is

${ }^{23}$ Arnaud Brohe, Nick Eyre, dan Nicholas Howarth. Carbon Markets: An International Business Guide. (London dan Sterling: Earthscan, 2009), p. 72. 
extremely significant for the development of the Kyoto Protocol, because it resulted in an agreement, known as the Marrakesh Accords. Marrakesh Accords is a long document of more than two hundred pages, and includes the modalities and procedures for the CDM. One important aspect of the $\mathrm{CDM}$ is the formation of its governing body, known as the Executive Council. The board members were appointed by the COP / MOP. Since the establishment of the Kyoto Protocol, decisions have been made by the COP / MOP to regulate CDM, JI and ET. ${ }^{24}$

Some of the more important issue was decided by the CDM Executive Board. These is about the approval and disapproval of the methodology that will be used to formulate the design documents for projects to reduce greenhouse gases and to measure the reduction of their actual, guidance additions, and approval and suspension of the DOE which validates and verifies the projects and the reduction of greenhouse gas emissions under the CDM.

Criticism of-process CDM has evolved as it has become increasingly inefficient and bureaucratic. International Emissions Trading Association (IETA) has issued a report with a fairly strong criticism of the CDM process and how the Executive Board and the staff who manage the process. ${ }^{25}$ IETA includes four structural deficiencies that prevent effective management, among others:

a. part time of government agencies;

b. Appropriate division of responsibility;

c. inadequate standardization; and

d. ignoring the legal process. ${ }^{26}$

There are five "enduring challenges" that "nearly suffocating CDM today":

a. time constraints unceasingly;

b. ineffective communication practices;

c. Lack of transparency;

d. slow policy development and inadequate resolution; and

e. inadequate number and expertise of staff of its secretariat. ${ }^{27}$

The discussion on measures to reduce greenhouse gas emissions do not stop until the Kyoto Protocol. There was still another COPs after Kyoto Protocol, among which the Bali Action Plan, Copenhagen Accord, Cancun, etc.

\footnotetext{
${ }^{24}$ Scott Deatherage. Op.cit., p. 46.

${ }^{25}$ Asosiasi Perdagangan Emisi Internasional, Negara CDM 2009: Reformasi untuk Saat Ini dan Mempersiapkan Masa Depan.

${ }^{26} \mathrm{Ibid}$.

${ }^{27}$ Ibid.
} 


\section{The Implementation of Carbon Trading in Indonesia}

As an archipelagic states, Indonesia is vulnerable to climate change impacts. Indonesia is one of the countries that ratified the United Nations Framework Convention on Climate Change (UNFCCC), through Law No. 6 of 1994.

By using a normative approach, this research is expected to find a permanent legal politics and incidental in the supervision of the constitutional judges. Based on primary and secondary legal materials; it concluded that in order to preserve and uphold the honor, dignity, and the behavior of the judge is required to supervise the attitude constitutional judge to fit the code of ethics, so that each judge's ruling will be implemented in order to enforce the law and justice based on Pancasila and 1945 Constitution as a permanent legal political for supervision of the constitutional judges. The Convention is one step of international societies in resolving the climate change issues, as a result of human activities that lead to increase greenhouse gas emissions, for example: the burning of fossil fuels to obtain energy, and the damage and loss of forest land. ${ }^{28}$ UNFCCC as a convention on climate change trying to find a way out by meetings between the participating countries, known as the Conference of the Parties (COP). As for one of the important achievements of the UNFCCC is the Kyoto Protocol (KP). Intrinsically, the Protocol contains two (2) important things: first, the commitment of the developed countries or Annex 1 parties to reduce the average emissions rate of 5.2\% compared to 1990; second, allowing the carbon trading mechanism that commonly known as flexible mechanism which can be carried out thru the clean development mechanism - CDM, joint implementation - JI; and emission trading - ET. ${ }^{29}$

The new mechanism that appears in the carbon trading related to forests is where industrial countries and polluting countries given an opportunity to compensate by paying developing countries to stoke tropical forests they have, so "sequestration" happens (storage of large amounts carbon). ${ }^{30}$

Indonesia is the third country that has the largest tropical forest in the world. The abundant natural resources have an impact on the role and great responsibility for the global environment, so that the improvement of forest management potentially to receive international support. In the COP 17- in

${ }^{28}$ CIFOR. Hutan, pohon, dan Wanatani: Penghidupan, Bentang Alam dan Tata Kelola. (Bogor: CIFOR, 2011), p. 2.

${ }^{29}$ Doddy S. Sukardi. Loc.cit.

30 Abdul Razak. Kelayakan Kompensasi yang Ditawarkan dalam Perdagangan Karbon. Makalah Manajemen Hutan Lanjutan (KTMK 612). Program Pasca Sarjana/S2 - Program Studi Manajemen Konservasi Sumber Daya Aalam dan Lingkungan Universitas Gadjah Mada, Yogyakarta, p. 4. 
Durban, Indonesia confirmed that it will take steps to reduce $26 \%$ of gas emissions. ${ }^{31}$

Indonesia has ratified the KP through Law No. 17 of 2004. Underlying the Kyoto Protocol to realize the Clean Development Mechanism, the Government has given the limits of forest criteria as stipulated in Forestry Minister Regulation No. 14 of 2004 on Procedures for Afforestation and Reforestation in the framework of the Clean Development Mechanism (A / R CDM); mentioned that the forest in order to realize the Clean Development mechanism should have:

1. minimum forest area $-0.25 \mathrm{Ha}$;

2. percentage of crown cover $-30 \%$; and

3. minimum tree height -5 meters.

In Article 26 of the Forestry Law No. 41 explained that the utilization of protected forests could be the utilization of environmental services, while Article 28 also stipulates that production forests can be used for environmental services. This can be implemented through the utilization of the business license of environmental services. This permission may be granted to individuals, cooperatives, Private Owned Enterprises (BUMS) and State-owned Enterprises (BUMN) or Village-owned Enterprises (BUMDes). Carbon trading is a form of environmental services.

According to the Governemnt Regulation No. 34 of 2002 on Forest Management and Forest Management Planning, Forest Utilization and Use of Forest Areas, Exploitation of Environmental Services is a form of business to exploit the potential of environmental services with no damage to the environment and reduce the principal functions of the forest. Utilization of environmental services for forest protection (Article 20) and production forests (Article 27) can be either an eco-tourism, sports business, utilization of water, carbon trading business and the rescue efforts of forest and environment. The policies and government regulations that are specific to carbon trading did not exist, eventhough the government gave an opportunity in Law No. 41 of 1999 and Government Regulations No. 34 of 2002. One of the problems is that our forestry policies and legislations are always changing and less consistent. ${ }^{32}$

As a country that is not part of the Annex I Parties under the Kyoto Protocol, one of the reasons our government ratified the Kyoto Protocol is to be able to participate in CDM projects in the world. Because the CDM is a carbon trading mechanism that involves developing countries. Indonesia

31 Achmad Siddik Thoha. Peluang Komunitas dalam Perdagangan Karbon. Diakses dari: http://www.latin.or.id/berita-redd/44-peluang-hutan-komunitas-dan-perdagangankarbon.html on 21 October 2015, 11.30 WIB.

32 CIFOR. Warta Kebijakan No.8 - Perdagangan Karbon. Accesed by: www.cifor.org/acm/download/pub/wk/warta08.pdf on 8 March 2016. 00.16 WIB. 
plays a strategic role in the issue of climate change and carbon trading today. As a country that has a specific on tropical rainforests, Indonesia is not merely referred to as the potential country, but also world carbon producer. Currently, carbon is also considered to be an asset. ${ }^{33}$ Each hectare of natural forest could potentially absorb 200-300 tons of carbon per hectare, while the carbon price in the international market an average of 12 dollars per ton of carbon. Thus, the value of the carbon contained in the 88 million ha of forests amounted to USD 211.2 billion.

Indonesia as one of the countries that have ratified the Kyoto Protocol and also be able to participate in CDM projects have taken measures, such as those conducted by the Ministry of the Environment which established a National Commission for Clean Development Mechanism (KNMPB). This commission is a governmental organization established through the Minister of Environment Decree No. 206 of 2005 (July 21, 2005) which is responsible for the implementation of the clean development conducted in Indonesia. There are criterias to determine whether a CDM project can be implemented in Indonesia, among others:

1. environmental sustainability;

2. economic sustainability;

3. social sustainability; and

4. technological sustainability.

Indonesia with a fairly large forest area, and carbon trading compensation, surely have a great opportunity to increase revenue for development activities, which certainly can not disengage from the requirements set by the countries that buy carbon trading certificates from Indonesia. The next question is whether the value offered by the compensation of carbon trading is appropriate to the value of the benefit obtained by Indonesia. According to WALHI's coordinator - Bali Sri Widhiyanti, steps should be taken is to reduce the emissions of developed countries. The reality is that America and Australia opposed ways of reducing emissions and offer a solution in the form of carbon trading. Without a reduction in emissions, carbon trading will not be able to reduce the global climate that now has reached 0.6 degrees Celsius, because $85 \%$ of total world emissions come from developed countries.

WALHI deeply regretted if the Indonesian government moves ahead with plans to sell Indonesia's tropical forests covering an area of 91 million hectares for carbon sequestration at a price of 5-20 dollars, which is not comparable with the ecological disaster that happens in the past and in the future. Developed countries should provide compensation for all the

33 Nurdiansyah Dalidjo. Karbon dan Tantangan apengelolaan Hutan. Accesed by: http://disasterchannel.co/index.php/publik/view/15 on 21 October 2015, 11.40 WIB. 
disasters. Refers to the phenomenon that occurs above, it needs to be studied further about the readiness of Indonesia itself in the face of these policies on carbon trading. Many internal problems experienced by developing countries, although during this time, developed countries have been concerned to the the progress of developing countries. Many things that need to be prepared in Indonesia, include revamping the standard rules on carbon trading. ${ }^{34}$

There is a research on carbon compensation conducted in Costa Rica, wherein forested land owners got compensation for their forests and obliged to protect it. However, this study said that this model fits in applied in high welfare countries, where they have a high enough capital to maintain forests. ${ }^{35}$

But, it is just not effective to be applied in developing countries, cause' they prioritize their capital for the economic development, and tend to be only slightly for the forest development. Even the tendency that exists is the use of forests for capital in development. Those things could be seen on the existing reforestation projects; so many constraints, including the capital. It should be underlined that in afforestation is not just about planting, but also the maintenance, security and others that require lot of fund. Though the forms of activities have also been aided by outsiders concern about the preservation of forests in Indonesia. There are some factors caused an uneffectiveness of carbon trading system was implemented in Indonesia in spite of the nominal price offered, include: ${ }^{36}$

1. institutional readiness to coordinate the fund allocation is compensated. Expectations of this compensation are the fund can be enjoyed by the societies, so as to improve their lives, thus reducing their access to forests;

2. regulation readiness to regulate in detail starting from spatial to the distribution systems of compensation;

3. another problem is about status of forest that still overlap; it needs to be addressed first; dan

4. morality of all elements related to the use of a compensation fund, where the mission will be accomplished is how societies can prosper with the improvement of the local economy, thereby reducing the impact of their activities on the forest, which has been one of the obstacles on forest degradation.

\footnotetext{
${ }^{34}$ Loc.cit., Abdul Razak.

${ }^{35} \mathrm{Ibid}$.

${ }^{36}$ Ibid.
} 
However, if the condition of Indonesia has been more stable,both of economic and human resources, then the compensation is legitimate with considerations: $:^{37}$

1. without such compensations, it's been our duty to protect the environment (forest sustainability) by looking ecofeminism and instead anthropocentric; and

2. the compensation is an additional capital for Indonesia in environmental development, while the capital that had been allocated for the environmental development can be diverted for the purpose of strengthening the economic sector, without compromising the existing natural resources.

\section{Conclusion and Recommendation}

1. Conclusion

Global warming is one of the impacts of climate change, among others caused by an increase in greenhouse gas emissions. Climate change can not be avoided, but at least its impact can be minimized, either by joint efforts among countries through carbon trading. Carbon trading is one way of reducing emissions; the rights and obligations of the parties, wherein the tropical forested countries are required to maintain their forests to absorp global warming and industrial countries pay the the tropical forested countries that sustain the forests. Thus, market is the result of the trading. Based on the research results can be concluded as follows:

1. climate change is a result of the increase in greenhouse gas emissions, it makes the international societies work together to solve it. Through the first Earth Summit in Rio de Jenairo-Brazil in 1992, which produces among which the Convention on Climate Change (UNFCCC); one of the important achievements of the UNFCCC is the Kyoto Protocol; which essentially contains two important things (first, the commitment of developed countries / Annex-1 parties to reduce the average emission rate of 5.2\% compared with 1990; second, allowing the carbon trading mechanism through Joint Implementation, Emission Trading and Clean Development Mechanism); and

2. indonesia ratified the United Nations Framework Convention on Climate Change (UNFCCC), through Law No. 6 of 1994 and Indonesia also has ratified the Kyoto Protocol through Law No. 17 of 2004. After ratified those two Laws, there are some rules / regulations related to it, namely Forestry Minister Regulation No. 14 of 2004 on Procedures for Afforestation and Reforestation in the framework of the Clean Development mechanism (A / R CDM), Government Regulation No. 34

${ }^{37}$ Ibid. 
of 2002 on Forest Management and Forest Management Planning, Forest Utilization and Use of Forest Areas, Exploitation of Environmental Services (which in Article 20 and 27 explains that the service utilization of protected forests and production forests which include carbon trading business), etc. However, of all those regulations, government has not yet issued regulations in implementing carbon trading or the specific instructions. So far, it is still a lot going on pros and cons related to the practice of reducing emissions through carbon trading in the forestry sector. As for the cons is where our country is given the obligation to keep the forests to reduce the rate of emissions, while the developed countries can still produce emissions, although in this case the developed countries cooperate and provide dues / compensation for the emissions can be reduced by Indonesia.

\section{Recomendation}

Environmental issues are very important to note, especially on global warming, then, the business cooperation between the countries related to carbon trading should be continued, in order to maintain the sustainability of environment and help reducing the global warming.

Related to Indonesia, as a country that has large tropical forests, then by their cooperation in carbon trading is should be able to participate properly in the implementation of carbon trading and will ultimately bring about positive impacts on the economy of Indonesia.

\section{Bibliography}

\section{A. Books}

Akib, Muhammad, 2015, Aktualisasi Politik Hukum Lingkungan Dalam Penyelenggaraan Otonomi Daerah, Bandar Lampung: Universitas Lampung.

Asosiasi Perdagangan Emisi Internasional, Negara CDM, 2009, Reformasi untuk Saat Ini dan Mempersiapkan Masa Depan.

Brohe, Arnaud, Nick Eyre, dan Nicholas Howarth, 2009, Carbon Markets: An International Business Guide, London dan Sterling: Earthscan.

CIFOR, 2011, Hutan, Pohon, dan Wanatani: Penghidupan, Bentang Alam dan Tata Kelola, Bogor: CIFOR.

D. Anggraini, Syahrina, 2009, CDM dalam Bagan Ver.9.0, Jakarta: Carbon and Environtmental Research (CER) Indonesia.

D. Deatherage, Scott, 2011. Carbon Trading Law and Practice. New York: Oxford University Press. 
Ismu Budianto, Anto, 2001, Hukum dan Lingkungan Hidup Di Indonesia, Jakarta: Perpustakaan Nasional.

Razak, Abdul, Kelayakan Kompensasi yang Ditawarkan dalam Perdagangan Karbon, Makalah Manajemen Hutan Lanjutan (KTMK 612), Program Pasca Sarjana/S2- Program Studi Manajemen Konservasi Sumber Daya Alam dan Lingkungan Universitas Gadjah Mada, Yogyakarta.

\section{B. Law and International Agreement}

Kyoto Protocol To The United Nations Framework Convention On Climate Change, http://unfccc.int/kyoto_protocol/items/2830.php

United Nations Framework Convention On Climate Change, http://unfecc.int/2860.php.

The President Regulation Number 46 of 2008 on The National Council of Climate Change.

Law Republic Indonesia Number 6 of 1994 on Legalization of United Nations Framework Convention on Climate Change (Konvensi Kerangka Kerja Perserikatan Bangsa Bangsa Mengenai Perubahan Iklim)

Law Republic Indonesia Number 17 of 2004 on Legalization of Kyoto Protocol To The United Nations Framework Convention On Climate Change (Protokol Kyoto Atas Konvensi Kerangka Kerja Perserikatan Bangsa-Bangsa Tentang Perubahan Iklim)

\section{Web}

Badan Pengawas Perdagangan Berjangka Komoditi, Indonesia Produsen Emisi Karbon Dunia, http://www.bappebti.go.id/id/edu/articles /detail/2997.html

BreakingNews, http://ahlulbaitindonesia.org/berita/7518/bijak-dan-cerdashadapi-tantanganperubahan-iklim-di-indonesia-2/

CIFOR, Warta Kebijakan No.8 - Perdagangan Karbon, Diakses dari www.cifor.org/acm/download/pub/wk/warta08.pdf

Dalidjo, Nurdiansyah, Karbon dan Tantangan apengelolaan Hutan, Diakses dari: http://disasterchannel.co/index.php/publik/view/15

Dewan Nasional Perubahan Iklim, 2013, Mari berdagang karbon!, Jakarta: Sekretariat DNPI, http://worldagroforestry.org/regions/southeast_asia /publications?do=view_Pub_detail \&pub_no=TD0171-12.

Komnas MPB, http://pasarkarbon.dnpi.go.id/web/index.php/komnasmpb. html

Kompas.com, Perdagangan karbon, bagaimana menurut anda?, http://forum.kompas.com /green-global-warming/28753-perdagangankarbon-bagaimana-menurut-anda.htmI 
Prijadikusuma, Kusnandar, Tesis, Posisi Indonesia dalam perdagangan karbon, $\quad$ http://lib.ui.ac.id/file?file=digital/20316617-T31930Posisi\%20indonesia.pdf.

Repository. Diakses: http://repository.usu.ac.id/bitstream/123456789/25 539/3/Chapter\%20II.pdf

Rumah Iklim.org, Perubahan lklim, http://rumahiklim.org/masyarakat-adatdan-perubahaniklim/apa-itu-perubahan-iklini/mengapa-perubahaniklim-tedadi/

Rumah Iklim.org, Apa itu perubahan iklim? http://nunahiklim.org/mas yarakat-adat-danperubahan-iklim/apa-itu-perubahan-iklim/

S. Sukardi, Doddy, Kerjasama antara Kementrian Kehutanan, DNPI dan UN-REDD Indonesia, UN-REDD Programme,: http://www.unredd.net/index.php?option=com_docman\&task=doc_do wnload $\&$ gid $=8850 \&$ Itemid $=53$

Setyono, Prabang, 2011, Etika, Moral, Dan Bunuh Diri Lingkungan Dalam Perspektif Ekologi (Solusi Berbasis Environmental Insight Quotient, Lembaga Pengembangan Pendidikan (LPP) Universitas Sebelas Maret Surakarta: Jawa Tengah, http://lpp.uns.ac.id/bukuteks/ima ges/flippingbook/Etika,\%20Moral\%20dan\%20Bunuh\%20Diri\%20Lin gkungan\%20dalam\%20Perspektif"/o20Ekologi,\%20Dr.\%20Prabang\% 20Setyono,\%20M.Si/pdf/etika,moral.pd

Siddik Thoha, Achmad, Peluang Komunitas dalam Perdagangan Karbon. Diakses dari: http://www.latin.or.id/berita-redd/44-peluang-hutankomunitas-dan-perdagangan-karbon.html

Stone, Susan, 2010, Conservation International, Perubahan Iklim dan Peran Hutan, http://www.conservation.org/publications/documents/redd/Cl_ Climate_Change_and_the_Role_of_Forests_Bahasa_Manual_Komuni tas.pdf.

Suwedi, Nawa. Upaya Pencegahan dan Penanggulangan Dampak Pemanasan Global, Diakses dari http://ejurnal.bppt.go.id/index.php/JTL/article/view/431/495

United Nations Framework Convention On Climate Change, http://unfccc.int/2860.php

UNFCCC, "The mechanism under the kyoto /protocol:, the Join Implementation (JI), Emissions Trading (ET), dan Clean Development Mechanism (CDM), http://unfccc.int/kyoto_protocol/mechanism /items/I 673.php

Word Agroforestry Centre Southest Asia, Publication, http://worldagroforestry.org/regions

/southeast_asia/publications?do=view_pub_detail\&pub_no ${ }^{=}$TD0171-12 